\title{
Population Briefs, Vol. 10, no. 1
}

Population Council

Follow this and additional works at: https://knowledgecommons.popcouncil.org/ series_newsletters_popbriefs How does access to this work benefit you? Let us know!

\section{Recommended Citation}

Population Briefs 10(1): New York: Population Council, 2004. 
IN THIS ISSUE

- Education

- Biomedical Research

- Female Genital Cutting

- Operations Research

- Aging

\section{- Reproductive Health}

Women who reported

being uncircumcised

had the bighest

education rates of

the women surveyed. see page 3

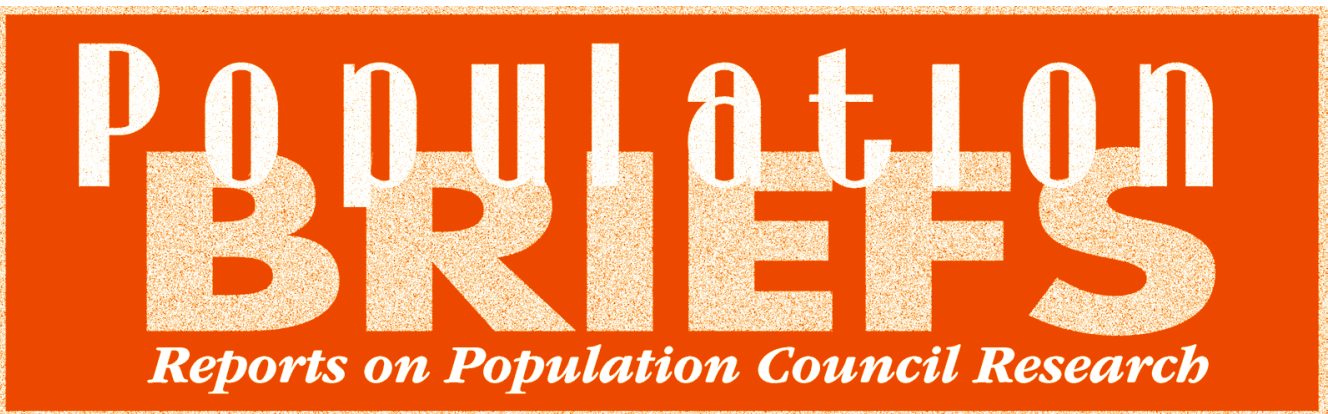

January 2004

Volume 10, Number 1

\section{Schooling Trends in Africa: New Assessment Methods Needed}

At least 37 million young people aged 10-14 in sub-Saharan Africa will not complete primary school, according to a recent analysis conducted by Population Council researchers. That number is nearly twice the total population of children aged 10-14 in the United States, virtually all of whom complete primary school. Moreover, nearly 21 million children in this age range in sub-Saharan Africa have never attended school.

In April 2000, at the World Education Forum in Dakar, Senegal, sub-Saharan African governments, along with others from around the world, recommitted themselves to achieving "Education for All” by 2015. Reaching this milestone by 2000 had previously been stated by the United Nations as one of its Millennium Development Goals.

The Population Council assessment, conducted by demographers Cynthia B. Lloyd and Paul C. Hewett, suggests that meeting this target will be difficult. Much needed are an international commitment to a greater level of resources, better tools for monitoring educational progress at the country level, and a focus on reaching the poorest families.

\section{Consistent and comparable data}

Currently, the United Nations Educational, Scientific, and Cultural Organization (UNESCO) monitors advancement toward universal primary schooling using enrollment data gathered by government ministries of education. This information is used to determine the net primary enrollment ratio and the grade four completion rate.
The Population Council analysis, however, suggests that these data draw an incomplete and potentially biased portrait of levels, trends, and gender differences in school participation and grade attainment.

The UNESCO net primary enrollment ratio is based on first-day enrollments as reported by schools to their national ministries of education. These numbers are divided by United Nations estimates of the population for the year and ages in question. In many countries, financial support to schools is directly related to levels of enrollment. Therefore, local education offices have substantial motivation to inflate these numbers. Furthermore, children who formally enroll may not attend school regularly and therefore, while officially counted as participating in school, do not actually attend.

Lloyd and Hewett recommend consulting an alternative data source, the Demographic and Health Surveys (DHS), from which net attendance rates can be derived. These rates are likely to provide a more realistic picture of participation in primary school in sub-Saharan Africa. Information in the DHS is collected through interviews with individuals in their homes and is highly representative of the total population of sub-Saharan Africa. The questionnaires provide comparable data on the educational participation and attainment of household members in many developing countries. 


\section{Carraguard ${ }^{\circledR}$ May Block HIV by Adhering to Cells}

HIV may be ferried deep into the body from the vagina by immune system cells known as macrophages, suggests new research conducted by Population Council virologist David M. Phillips and his colleagues. The research also showed that the Council's lead candidate microbicide gel, Carraguard $^{\circledR}$, is effective at reducing this form of HIV transmission in lab animals. The Population Council is preparing to enter into large-scale efficacy trials to test Carraguard's efficacy in blocking HIV transmission in 4,000 nonpregnant women. The microbicide will be one of the first products of its kind to enter this advanced phase of research.

The active ingredient in Carraguard is carrageenan, a substance derived from seaweed. Carrageenan compounds are on the U.S. Food and Drug Administration's list of GRAS (generally recognized as safe) products for consumption and topical application.

The term "microbicide" refers to a range of products, in cream, gel, film, or suppository form, that would substantially reduce the transmission of HIV—and possibly other sexually transmitted infections (STIs) — when applied topically. If proven viable, these products would offer a powerful new prevention tool in the fight against AIDS. Globally, women's rates of HIV infection are growing more rapidly than men's, and the current strategies for preventionmutual monogamy among HIV-negative partners, condom use, and treatment of existing STIs - are not practical for many women. Because of this urgent need for a womancontrolled product, and one that does not necessarily prevent pregnancy, the Population Council has focused to date on a vaginal, noncontraceptive microbicide.

\section{Macrophage trafficking}

Previous research by Phillips and others has suggested that macrophages, which ingest invading microbes, can migrate from the intact surface of the inside of the vagina to lymph nodes and other immune system structures inside the body. Some investigators have suggested that HIV-infected macrophages in semen can act as Trojan horses, transporting HIV into the body as they conduct their normal immune system duties.

To confirm whether macrophages could indeed make this journey, Phillips and his colleagues stained live mouse macrophages with an orange dye. They then inserted these cells into the vaginas of mice. Four hours later, the immune system organs were removed from the mice and processed. The investigators discovered an average of 55 orange-dyed macrophages per animal in lymph nodes from the pelvic and groin region. They also found an average of 558 orange-dyed macrophages per animal in the spleen, an immune system organ located just below the diaphragm.

The next step was to test the effectiveness of Carraguard against that of a placebo. The researchers used methylcellulose, a gel similar in appearance and consistency to Carraguard. This time, Phillips and his team treated mice vaginally with either Carraguard or methylcellulose 20 minutes in advance of introducing the macrophages.

In mice that received a vaginal pretreatment with Carraguard, an average of only four orange-dyed macrophages were found in lymph nodes per animal. An average of only 28 such macrophages were discovered in the animals' spleens. When the mice were pretreated with methylcellulose, an average of 26 macrophages reached the lymph nodes and 153 homed in on the spleen. The difference in the number of macrophages seen in these immune system organs between the Carraguard- and the methylcellulose-treated mice was statistically significant. The difference in these measures between Carraguard-treated and untreated animals was highly significant, whereas the difference between methylcellulose-treated and untreated mice was not significant.

\section{Mechanism of action}

Eager to learn how Carraguard kept macrophages out of the body, Phillips and his team placed the cells in culture dishes containing either Carraguard or methylcellulose. They also left some macrophages unexposed to either substance. They wanted to see whether either substance could kill macrophages outright. They found that, although the viability of the macrophages exposed to Carraguard and methylcellulose was reduced somewhat compared to the unexposed macrophages, the exposed cells fared similarly. Some other mechanism must account for the inhibition of HIV transmission seen with Carraguard.

The researchers then sought to determine whether Carraguard prevented macrophage movement by binding to them. They used a technique that detects only carrageenan firmly attached to cells. They found that Carraguard adhered to both macrophages and the cells in the vagina. Because carrageenan is a large molecule that cannot enter the body through the vagina, "this binding is likely the mechanism that reduced the number of macrophages that traveled from the vagina to the lymph nodes and spleen," says Phillips.

HIV may have several means of entering the body, the scientists note. Thus, it is important to develop microbicides that block HIV transmission in many ways. The Population Council continues to investigate ways of broadening the mechanisms that its candidate microbicides use to reduce HIV transmission.

\section{SOURCE}

Perotti, Maria-Elisa, Alessia Pirovano, and David M. Phillips. 2003. "Carrageenan formulation prevents macrophage trafficking from vagina: Implications for microbicide development," Biology of Reproduction 69(3): 933-939.

\section{OUTSIDE FUNDING}

MIUR/University of Milan, the National Institute of Allergy and Infectious Diseases, the National Institute of Child Health and Human Development, and the Rockefeller Foundation

Since the printing of this newsletter, the Population Council has expanded the trial to four clinics and plans to enroll a total of 6,270 women. 


\section{Potential Data Biases in Studies Exposed}

Female genital cutting (FGC), also known as female circumcision and female genital mutilation, has been the topic of much research and attention in the past ten years. Investigators seek to learn the prevalence of the procedure in a certain area, to ascertain the determinants of the practice, and to verify the effects of interventions aimed at reducing the incidence of the custom. Findings from a recent study conducted by the Population Council, however, suggest that results of such investigations should be interpreted with caution. Women interviewed about FGC may falsely deny or falsely confirm having undergone the procedure.

\section{Navrongo Health Research Centre}

The study is part of an experimental investigation in health services delivery launched by the Navrongo Health Research Centre in the Kassena-Nankana District of northeastern Ghana. The Centre's core scientific resource is the Navrongo Demographic Surveillance System. Using this system, developed in part by Population Council demographer James F. Phillips, investigators have recorded demographic events among all residents of the area since 1993.

Yearly surveys collect more detailed information from a subset of women aged 15-49. In 1995 and 2000, for example, among the questions the survey asked women was, "Are you circumcised?" Almost 2,400 of the 5,275 women surveyed in 1995 answered the question again in 2000. Because of high rates of migration, fewer than half the women interviewed in 1995 were reinterviewed in 2000.

The responses from women who participated in both surveys were analyzed and the respondents were placed into four categories. In the first two categories were women whose survey answers in the two years agreed. In both surveys they reported either that they had or had not undergone circumcision. In the other two categories were women whose two survey answers disagreed. Some of these women said in the first survey that they had not been circum- cised, but in the second survey said they had been. The researchers assumed that the women underwent circumcision in the time period between the two surveys. The rest of the women reported in the first survey that they had been circumcised, but subsequently said they had not been — an impossible sequence of events.

A relatively high rate of response reversal was not completely unexpected. In the past, nearly all women in the Kassena-Nankana area were circumcised, and women who avoided the procedure were stigmatized. In 1994, however, the government of Ghana passed a law banning female genital cutting, and in

\section{Women interviewed}

about FGC may falsely

deny or falsely con-

firm baving under-

gone the procedure.

1996 a circumciser in the Kassena-Nankana area was jailed. In the past several years there has been a notable decrease in the stigma attached to women who are not circumcised.

There may be more than one explanation for response reversal. Women may be falsely denying circumcision. Or they may have incorrectly reported circumcision in the first survey because they felt pressured to give what they thought was a socially appropriate response. Because being uncircumcised had become less stigmatized by 2000 , these women may have felt more comfortable reporting their true status.

The gold standard for settling this issue would be to conduct physical examinations of survey respondents. This method has drawbacks, however. Medical examinations require specially trained personnel and thus are costly. Moreover, many women may not agree to being examined, producing a biased sample.

\section{Data analysis}

The researchers analyzed the survey data to compare the marital status, education, and other characteristics of women who fell into each category. They found that women who in both surveys reported being uncircumcised had the highest education rates of the women surveyed. They were also more likely than other women to have used family planning and less likely to practice a traditional religion or be in a polygamous marriage. Women who reported being circumcised in the first survey but later denied it appear to occupy a middle ground. They are more likely to be educated and less likely to practice traditional religion than are women who reported circumcision in both surveys. And they are less likely to be educated and more likely to practice traditional religion than are women who never reported being circumcised.

Besides biasing data about the incidence of circumcision, the false reporting of circumcision status can influence conclusions drawn about the determinants of the practice. "If we had access only to the survey answers from 2000, we would have underestimated the influence of education, traditional religion, and marital status on circumcision," says lead researcher Elizabeth F. Jackson, a Population Council staff associate at the time of the study. The researchers conclude that investigators should use caution when interpreting data on female genital cutting that are collected at a single point in time. In such studies, determining the rate of false reporting of circumcision status is more difficult than in other studies.

\footnotetext{
SOURCE

Jackson, Elizabeth F., Patricia Akweongo, Evelyn

Sakeah, Abraham Hodgson, Rofina Asuru, and James F. Phillips. 2003. "Inconsistent reporting of female genital cutting status in northern Ghana: Explanatory factors and analytical consequences," Studies in Family Planning 34(3): 200-210. This study also appeared as Policy Research Division Working Paper no. 178. New York: Population Council (www.popcouncil.org/pdfs/wp/178.pdf).

OUTSIDE FUNDING

United States Agency for International Development
} 


\section{Enhancing HIV/AIDS Care in South India}

As of 2002, nearly 4 million adults in India were infected with HIV, according to UNAIDS. The number of new HIV infections in India is rapidly increasing, and the health care system is experiencing a substantial growth in the demand for services. To address this challenge, the Population Council's Horizons program began collaborating with the International HIV/AIDS Alliance in September 1999 to examine the experiences of the Y.R. Gaitonde Centre for AIDS Research and Education (YRG CARE), a nongovernmental organization based in Chennai, India. YRG CARE provides a range of successful prevention, care, and support services for people with HIV/AIDS. The organization wanted to expand services in Chennai as well as introduce its style of services to organizations in four other locations in India: Calicut, Chirala, Mysore, and Pondicherry. Horizons employed operations research to facilitate this expansion of services.

In the HIV/AIDS field, operations research applies systematic research techniques to analyze factors that are under the control of program managers, such as improving the quality of services and counseling. An important objective of operations research is to provide managers with the information they need to improve and expand services.

This Horizons study includes components focusing on clients' quality of life and satisfaction with services, in addition to institutional costs, clients' willingness to pay for services, and the effect of treatment costs on clients' budgets. The researchers investigated these issues using client surveys and in-depth interviews, personnel training and assessment, and the development of case studies for each location.

The USAID-funded Horizons research program is implemented by the Population Council in collaboration with the International Center for Research on Women, the International HIV/AIDS Alliance, the Program for Appropriate Technology in Health, Tulane University, Johns Hopkins University, and Family Health International.

\section{Scaling up}

Because of its reputation as a source of highquality, affordable, and confidential care, YRG CARE has attracted clients not only from the Chennai area but from throughout South India, some of whom travel hundreds of miles for services. From its facilities in Chennai, the organization provides voluntary HIV counseling and testing, nutrition counseling, inpatient and outpatient care, and many other services. One of the main goals of the study was to find ways to transfer the clinic's services and core concept — providing economical, high-quality HIV/AIDS care- to the new locations without necessarily imposing the Chennai managerial structure.

"It's important to acknowledge that concepts and values rather than rigid organizational structures and models are the critical elements to export to a new environment," says Chris Castle of Horizons/International HIV/AIDS Alliance.

For example, most of the services available at YRG CARE are provided in-house, with a few services being outsourced. In contrast, some of the scale-up sites, particularly the one in Calicut, found it best to outsource many of their services to trusted collaborators. As partnerships and networking intensified, referrals grew and care options increased.

In Chirala, researchers and collaborators discovered a need to emphasize counseling over other services. A manager there noted, "In Chirala, many testing centers are present, but many do not give counseling. So we want to take counseling as the first priority."

\section{Willingness-to-pay surveys}

Meeting clients' needs and maintaining quality of care while remaining solvent is one of the toughest issues facing any nonprofit service provider. In order to do this, many organizations must impose or increase service fees. The challenge is to increase fees to an amount that clients are willing and able to pay while ensur- ing that the poorest clients can continue to access those services. One way of investigating these issues is to conduct a willingness-to-pay survey. Using this method, the researchers found that clients value YRG CARE's services and show considerable willingness to pay higher fees for services. Client responses indicated that although some could spend less on amenities to meet higher costs, most would seek money from friends or family members.

Another way of increasing sustainability is to more efficiently manage donated money and funds from existing sources. The research suggested that YRG CARE could expand its client base without reducing the quality of its services. Doing this would offset such fixed costs as rent and salaries. The organization could also use revenues gathered from more lucrative services to pay for deficits incurred by other services.

"It is unreasonable to expect that nongovernmental organizations, which serve some of the most disenfranchised members of society, can rely solely on user fees to offset the cost of providing care and support," explains Rick Homan of Family Health International, a Horizons partner.

Future research efforts on the YRG CARE scale-up are likely to explore strategies for further improving the quality of service provision and for expanding access to antiretroviral therapy.

\footnotetext{
SOURCES

Castle, Chris. 2003. Expanding Care and Support in South India: Scaling Up YRG CARE's Patient-Centered Approach. Washington, DC: Population Council.

Castle, Chris. 2003. "YRG CARE base model report: Integrated prevention, care, and support services," Horizons project report. Washington, DC: Population Council.

Dadian, Margaret (ed.). 2002. Horizons Report: Care and Support in India-Special Focus on YRG CARE. Washington, DC: Population Council.

OUTSIDE FUNDING

United States Agency for International Development
} 


\section{How Long Will We Live? Demographers Refine Estimates}

Estimates of current life expectancy at birth are routinely provided by national and international statistical agencies. These figures are important to policymakers because they measure progress in lowering a country's overall level of mortality. Expected future trends are crucial to government officials, who project public health care and pension expenditures. The United Nations Population Division publishes estimates of life expectancy for all countries in the world, ranging from a low of 37 years in Sierra Leone to a high of 80 years in Japan for the period 1995-2000. In the United States, estimates are 74 years for men and 79 years for women in 1997.

These numbers, based on one of the oldest and most fundamental tools of demography, may be overestimated by up to a few years in contemporary countries with high life expectancy, say two demographers who have analyzed past and projected trends in mortality. In a paper published in the Proceedings of the National Academy of Sciences, John Bongaarts and Griffith Feeney question the accuracy of the underlying calculations that generate life expectancy figures. Bongaarts, vice president and director of the Population Council's Policy Research Division, and Feeney, an independent consultant, identify a distortion in the calculations and provide a formula to amend the figures.

The distortion, which Bongaarts and Feeney term the "tempo effect," has long been recognized by demographers studying fertility; the authors are the first to apply the calculations to mortality. In the case of fertility, tempo refers to the timing of childbirth: when women delay childbearing to later in life, fewer births occur in a particular year. Conversely, when women have children at a younger age, the number of births in a particular year will be inflated. The postwar "baby boom" in the United States, for example, was due in part to a decline in the average age at childbearing during the late 1940s and 1950s. Similarly, the low

fertility observed throughout much of the 1970s and 1980s in the United States, western Europe, and Japan was in part due to an increasing age at childbearing, rather than an actual decrease in births per woman, the authors say.

According to Bongaarts and Feeney, the tempo effect influences mortality rates in much the same way. The medical advances currently experienced by developed countries raise the average age of death, whereas a deadly epidemic like AIDS can lower the age.

"We don't live quite

as long as we thought

we did."

\section{We don't live quite as long}

The tempo effect is most readily demonstrated in contemporary societies with high life expectancy, such as Japan, the United States, and many European countries. Based on the demographers' calculations, removal of the tempo effect reduces estimates of life expectancy for women by 1.6 years in the United States and Sweden, by 2.4 years in France, and by 3.3 years in Japan for the period 1980-95.

While a reduction of two or three years may not seem like a big difference on the individual level, the societal implications are considerable. "We don't live quite as long as we thought we did," Bongaarts says. "And in the long run, two or three years can have a substantial impact on the total future expenditures on pensions and health care for the elderly."

Furthermore, the differences between countries are quite substantial and somewhat surprising, Bongaarts notes. In Japan, life expectancy for women is currently 83 years, while in western Europe the average is 81 for
1995-2000. Current population projections assume that the rest of the world will eventually converge to Japan's level. "We demonstrated that Japan's number has the largest distortion. If you eliminate the distortions, Japan ends up looking very much like France or Sweden," Bongaarts says. The distortion in Japan is larger than in the other countries because the tempo effect depends on the rate at which life expectancy is rising - the more rapid the rise, the greater the distortion. During the last 25 years, life expectancy in Japan has been rapidly rising, outpacing relatively modest gains experienced by the United States and western European countries.

\section{Are there limits to life spans?}

The heart of the issue is not necessarily how long we live now, but how high life expectancy will rise and whether there is a limit on those advances, Bongaarts says. Scholars are divided into two camps. The optimists- those who see gains in life expectancy of a few years each decade_ — predict life spans as great as 100 years by 2050. The pessimists - those who believe in biological limits — think we may be nearing the maximum longevity. "If the optimists are right and we continue to gain years in life expectancy, then the health care costs and pension costs are going to be higher than expected. If the pessimists are right, then the current projections are too high," Bongaarts says. Although the new findings don't resolve this controversy, the study lends more support to the pessimists' point of view.

\section{SOURCE}

Bongaarts, John and Griffith Feeney. 2003. "Estimating mean life time," Proceedings of the National Academy of Sciences 100(23): 13127-13133.

\section{OUTSIDE FUNDING}

The William and Flora Hewlett Foundation and the Andrew W. Mellon Foundation 


\section{Investigating IUD Demand in Ghana and Guatemala}

As the longest-acting method of reversible contraception available, the intrauterine device (IUD) has long been considered one of the most effective — and cost-effective — of contraceptive options. Once placed in the uterus, the device requires little attention and remains functional for ten years. Medically, the IUD is well suited for women who are in a stable, mutually monogamous relationship and are not at risk for sexually transmitted infections (STIs) and pelvic inflammatory disease. Like other nonbarrier methods of birth control, the IUD does not protect against HIV/AIDS or other STIs, but it can be combined with condom use when a woman desiring long-term contraception is unsure of her partner's HIV or STI status.

When researchers and policymakers in Ghana and Guatemala noticed a drop in IUD use over the past few years, they wondered why. Had the method gained a bad reputation, were clients poorly informed, was the quality of services poor? Although the research teams were working separately—using different survey questions and methods of analysis - their findings point to the same explanations: lack of knowledge among providers and clients, logistical problems, and cumbersome clinic guidelines. Myths and rumors also surrounded the method, with both providers and potential clients misinformed about the IUD's side effects and contraindications.

The researchers concluded that efforts to increase use should include more comprehensive training of providers; better counseling to make sure that providers discuss not only IUDs, but all relevant methods; more comprehensive training of providers; and logistical support for clinics.

The studies in Ghana and Guatemala were sponsored by the Population Council's Frontiers in Reproductive Health program, designed to improve the delivery of family planning and reproductive health services in developing countries. Researchers surveyed public, private, and nongovernmental health clinics in both rural and urban settings. They relied on focus groups, in-depth interviews, and visits to providers by women who posed as

clients to examine providers' and clients'

knowledge and attitudes about IUDs.

According to study authors Carlos

Brambila and Berta Taracena, IUD use in Guatemala is considered low relative to the estimated demand for long-term methods. The prevalence of contraceptive use among women in marriages and partnerships in Guatemala is 38 percent; of these only 2 percent use IUDs.

"A majority of family

planning providers did

not mention the IUD

to their clients at all."

\section{Surprising findings}

The Guatemalan study revealed that providers frequently offer insufficient information to allow women to make an informed choice regarding IUDs. "A majority of family planning providers did not mention the IUD to their clients at all," the authors report. In Ghana, where data on current contraceptive use show a drop in IUD use from 4 percent in 1988 to less than 3 percent in 1998, Population Council researchers Ian Askew and Harriet Birungi and colleagues John Gyapong and Ivy Osei of the Ghana Health Research Unit found that providers in general have a favorable attitude toward the method. "They offer it to clients as one of the options and actually make the attempt to dispel associated rumors," the researchers report.

Women in both countries mentioned known side effects such as cramping and bleeding as reasons for not using the IUD; in focus groups, however, the IUD was also blamed for causing marital disharmony, cancer, and abortion. Women worried that IUDs could fail, cause heavy bleeding, get lost inside the body, or stick to the unborn child.
In Guatemala, close to 90 percent of clinics had the necessary facilities (a clean, private room) and at least one worker trained in IUD insertion and removal, but about half lacked the supplies and equipment (IUD insertion kits and gloves) to offer these services. The reverse was true in Ghana, where only 56 percent of the clinics had the facilities to offer IUDs, but 91 percent had the necessary supplies available. Furthermore, focus group members in Guatemala said that the need to travel to urban clinics made IUDs too expensive. In Ghana, only doctors and midwives - not nurses - are allowed to insert IUDs, a policy that further restricts access.

\section{Policy implications}

The researchers and policymakers make several recommendations. Educational efforts should focus on the IUD's positive attributes as well as the contraindications of the product, and marketing efforts should focus on increasing the method's visibility. Clinical guidelines should be revised to incorporate the training of paraprofessionals and nonmedical staff, and testimonials of satisfied clients could be used to dispel rumors and demystify the product.

Already changes are underway. In Ghana the study's findings are being disseminated to providers nationwide; in Guatemala, nurse auxiliaries are being trained in IUD service provision, including counseling and clinical care. Furthermore, researchers in both countries are developing and testing strategies to increase people's awareness of the IUD's advantages.

\section{SOURCES}

Gyapong, John, Gifty Addico, Ivy Osei, Mercy Abbey, Dominic Atweam Kobinah, Henrietta Odoi Agyarko, Gloria Quansah Asare, Harriet Birungi, and lan Askew. 2003. "An assessment of trends in the use of the IUD in Ghana," Frontiers and Ghana Health Service report. Washington, DC: Population Council.

Brambila, Carlos and Berta Taracena. 2003. "Availability and acceptability of IUDs in Guatemala," Frontiers final report. Washington, DC: Population Council.

OUTSIDE FUNDING

United States Agency for International Development 


\section{RECENT PUBLICATIONS}

\section{Biomedical Research}

Product development

Anderson, R.A., A.M. Wallace, N. Sattar, N. Kumar, and K. Sundaram. "Evidence for tissue selectivity of the synthetic androgen $7 \alpha$ methyl-19-nortestosterone in hypogonadal men," Journal of Clinical Endocrinology and Metabolism 88(6): 2784-2793.

Sitruk-Ware, R. "Hormone therapy and the cardiovascular system: The critical role of progestins," Climacteric 6(suppl 3): 21-28.

Reproductive physiology

Bernard, D.J. "Inhibin receptor signaling," in H.L. Henry and A.W. Norman (eds.), Encyclopedia of Hormones. New York: Academic Press, pp. 297-303.

Bernard, D.J., K.H. Burns, B. Haupt, M.M. Matzuk, and T.K. Woodruff. "Normal reproductive function in InhBP/p120-deficient mice," Molecular and Cellular Biology 23(14): 4882-4891.

\section{Building Research Capability} and Tools

Developing or adapting research tools Health, Development, Information and Policy Institute. "Creation of a unified management information system for three NGOs in the West Bank and Gaza," Frontiers final report. Washington, DC: Population Council.

"Mobilize policy champion teams to foster utilization of management tools," Frontiers OR summary. Washington, DC: Population Council.

World Health Organization and Frontiers Program. “Expanding capacity for operations research in reproductive health: Summary report of a consultative meeting." Geneva: World Health Organization.

\section{Gender and Family Dynamics}

Langer, Ana and Blanca Rico. "An integral initiative to respond to complex needs," in Paz López, Blanca Rico, Ana Langer, and Guadalupe Espinosa (eds.), Género y Política en Salud [Gender and health policy]. Mexico City: UNIFEM, Salud.

López, Paz, Blanca Rico, Ana Langer, and Guadalupe Espinosa (eds.). Género y Política en Salud [Gender and health policy]. Mexico City: UNIFEM, Salud.

Girls' and women's livelihoods

Amin, Sajeda and Nagah H. Al-Bassusi. “Wage work and marriage: Perspectives of Egyptian working women," Policy Research Division Working Paper no. 171. New York: Population Council.

\section{Violence against women}

Boonmongkon, Pimpawum, Philip Guest, Amporn Marddent, and Steve Sanders. "From trafficking to sex worker: Burmese migrants in Thailand," in M. Darwin, A.M. Wattie, and S.E. Yuarsi (eds.), Living on the Edges: Cross-

Border Mobility and Sexual Exploitation in the Greater Southeast Asia Sub-Region.

Yogyakarta: University of Gadjah Mada, pp. 163-232.

Verma, Ravi K. and Martine Collumbien. "Wife beating and the link with poor sexual health and risk behavior among men in urban slums in India," Journal of Comparative Family Studies 34(1): 61-74.

\section{HIV/AIDS}

Dadian, Margaret (ed.). Horizons Report: Workplace Studies in Africa and Asia. Washington, DC: Population Council.

Basic science of infection

Pope, M.J. “Dendritic cells as a conduit to improve HIV vaccines," Current Molecular Medicine 3(3): 229-242.

\section{-. "Nefarious abuse," Nature Immunology 4(8): 729-730}

Pope, M.J. and A.T. Haase. "Transmission, acute HIV-1 infection and the quest for strategies to prevent infection," Nature Medicine 9(7): 847-852.

Teleshova, N., I. Frank, and M.J. Pope.

"Immunodeficiency virus exploitation of dendritic cells in the early steps of infection," Journal of Leukocyte Biology, published online 22 July. Veazey, R.S., P.J. Klasse, R.J. Shattock, M.J. Pope, J.C. Kirijan, J. Jones, T. Ketas, P.A. Marx, D.R. Burton, and J.P. Moore. "Vaginal application of anti-gp120 monoclonal antibody b12 prevents SHIV162P vaginal transmission in macaques," in B. Dodet and M. Girard (eds.), Proceedings of XIII Colloque des "Cent Gardes." New York: Elsevier, pp. 51-57.

\section{Prevention}

Jones, Heidi, Janneke van de Wijgert, and Elizabeth Kelvin. "The need for a 'condomsonly' control group in microbicide trials," Epidemiology 14(4): 505.

Pulerwitz, Julie, Johannes van Dam, and Natalie Phillips-Hamblett. "The ABCs and beyond: Developing an operations research agenda on comprehensive behavior change approaches for HIV/AIDS prevention: Report from a technical meeting," Horizons project report. Washington, DC: Population Council.

Vu Ngoc Bao, Philip Guest, Julie Pulerwitz, Le Thuy Lan Thao, Duong Xuan Dinh, Tran Thi Kim Xuyen, and Anne Levin. “Expanding workplace
HIV/AIDS prevention activities for a highly mobile population: Construction workers in $\mathrm{Ho}$ Chi Minh City," Horizons project report. Washington, DC: Population Council.

Treatment, care, and support

Castle, Chris. "YRG CARE base model report: Integrated prevention, care, and support services," Horizons project report. Washington, DC: Population Council.

Hope Humana, LINKAGES, National Food and Nutrition Commission, Ndola District Health Management Team, Horizons Program, and Zambia Integrated Health Project. “Empowering communities to respond to HIV/AIDS: Ndola Demonstration Project on Maternal and Child Health: Operations research final report," Horizons project report. Washington, DC: Population Council.

Youth

"Involving youth in the care and support of people affected by HIV and AIDS," Horizons research summary. Washington, DC: Population Council.

"Succession planning in Uganda: Early outreach for AIDS-affected children and their families," Horizons research summary. Washington, DC: Population Council.

Population and

Social Science Research

Journal

Population and Development Review 29(3)

Aging

Freedman, Vicki A. and Linda G. Martin.

"Beyond inconsistent results: Finding the truth about trends in late-life cognitive functioning," Journals of Gerontology 58B(6): S347-S348.

Zimmer, Zachary, Napaporn Chayovan, HuiSheng Lin, and Josefina Natividad. "How indicators of socioeconomic status relate to physical functioning of older adults in three Asian countries," Policy Research Division Working Paper no. 172. New York: Population Council.

Zimmer, Zachary and Julia Dayton. “The living arrangements of older adults in sub-Saharan Africa in a time of HIV/AIDS," Policy Research Division Working Paper no. 169. New York: Population Council.

Fertility and reproductive behavior

Agyei-Mensah, Samuel and John B. Casterline (eds.). Reproduction and Social Context in SubSaharan Africa: A Collection of MicroDemographic Studies. Westport, CT: Greenwood Press.

continued on page $7 A$ 
continued from page 7

. "Reproduction and social context in sub-Saharan Africa: An introduction," in Samuel Agyei-Mensah and John B. Casterline (eds.), Reproduction and Social Context in Sub-Saharan Africa: A Collection of Micro-Demographic Studies. Westport, CT: Greenwood Press, pp. 1-5. Agyeman, Dominic K. and John B. Casterline. "Social organization and reproductive behavior in southern Ghana," in Samuel Agyei-Mensah and John B. Casterline (eds.), Reproduction and Social Context in Sub-Saharan Africa: A Collection of Micro-Demographic Studies. Westport, CT: Greenwood Press, pp. 7-35.

Bongaarts, John. “Completing the fertility transition in the developing world: The role of educational differences and fertility preferences," Policy Research Division Working Paper no. 177. New York: Population Council.

. "Fertility, proximate determinants of," in Paul Demeny and Geoffrey McNicoll (eds.), Encyclopedia of Population, vol. 1. New York: Macmillan Reference USA, pp. 412-417.

Casterline, John B. “Demographic transition," in Paul Demeny and Geoffrey McNicoll (eds.), Encyclopedia of Population, vol. 1. New York: Macmillan Reference USA, pp. 210-216.

. "Freedman, Ronald," in Paul Demeny and Geoffrey McNicoll (eds.), Encyclopedia of Population, vol. 1. New York: Macmillan Reference USA, pp. 438-439.

Htay, Thein Thein, Josephine Sauvarin, and Saba Khan. "Integration of post-abortion care: The role of township medical officers and midwives in Myanmar," Reproductive Health Matters 11(21): 27-36.

Islam, M., U. Rob, and N. Chakroborty.

"Regional variations in fertility in Bangladesh," Genus LIX(3).

Marindo, Ravai, Steve Pearson, and John B.

Casterline. "Condom use and abstinence among unmarried young people in Zimbabwe: Which strategy, whose agenda?" Policy Research Division Working Paper no. 170. New York: Population Council.

Policy development

Bongaarts, John. 2001. "Population forecasts," in Lester Breslow (ed.), Encyclopedia of Public Health. New York: Macmillan Reference USA, p. 942.

Demeny, Paul. "Population policy: A concise summary," Policy Research Division Working Paper no. 173. New York: Population Council.

McNicoll, Geoffrey. “Demographic transition," in Joel Mokyr (ed.), The Oxford Encyclopedia of Economic History. New York: Oxford University Press, pp. 71-74.
—. "Introduction: Australia's population history and prospects," in Siew-Ean Khoo and Peter McDonald (eds.), The Transformation of Australia's Population: 1970-2030. Sydney: University of New South Wales Press, pp. 1-16. “Population and development: An introductory view," Policy Research Division Working Paper no. 174. New York: Population Council.

Quality of Care/Quality of Services

Expanding contraceptive choices

Sanogo, Diouratié, Saumya RamaRao, Heidi Jones, Penda N'Diaye, Bineta M'bow, and Cheikh Bamba Diop. "Improving quality of care and use of contraceptives in Senegal," African Journal of Reproductive Health 7(2): 57-73.

Gyapong, John, Gifty Addico, Ivy Osei, Mercy Abbey, Dominic Atweam Kobinah, Henrietta Odoi Agyarko, Gloria Quansah Asare, Harriet Birungi, and lan Askew. "An assessment of trends in the use of the IUD in Ghana," Frontiers and Ghana Health Service report. Washington, DC: Population Council.

General quality of care improvement

León, Federico R., Alex Rios, Adriana Zumaran, Marisela de la Cruz, Carlos Brambila, and John H. Bratt. "Enhancing quality for clients: The balanced counseling strategy," Frontiers Program Brief no. 3. Washington, DC: Population Council.

\section{Reproductive Health}

Langer, Ana. "Sexual and reproductive health: Where are we almost a decade after Cairo?" in M. Bronfman and C.E. Denman (eds.), Reproductive Health: Fears and Debates. Cuernavaca: Instituto Nacional de Salud Pública, pp. 25-34.

Journal

Studies in Family Planning 34(3)

Adolescents

Institut de Recherche et des Etudes des Comportements. "Peer education as a strategy to increase contraceptive prevalence and reduce the rate of STIS/HIV among adolescents in Cameroon," Frontiers final report. Washington, DC: Population Council.

Janowitz, Barbara, Carmen Cuthbert, Mags Beksinka, and Queen Cebekhulu. “The cost of programmes at selected youth centres in South Africa," Frontiers report. Washington, DC: Population Council.

\section{Contraception}

Brambila, Carlos and Berta Taracena.

"Availability and acceptability of IUDs in Guatemala," Frontiers final report. Washington, DC: Population Council.
“Clients and providers need better support and guidance on IUD," Frontiers OR summary. Washington, DC: Population Council.

Family planning and reproductive health programs

Guest, Philip. “Reproductive health including family planning," Asia-Pacific Population Journal 18(2): 55-79.

Ulloa-Aguirre, Alfredo and C. Diaz-Olavarrieta. "Preface," Gaceta Médica de México 139(suppl 1): S1-S2.

Female genital cutting

Jackson, Elizabeth F., Patricia Akweongo, Evelyn Sakeah, Abraham Hodgson, Rofina Asuru, and James F. Phillips. "Women's denial of having experienced female genital cutting in northern Ghana: Explanatory factors and consequences for analysis of survey data," Policy Research Division Working Paper no. 178. New York: Population Council.

Large-scale experimental programs

Phillips, James F., Tanya C. Jones, Frank K. Nyonator, and Shruti Ravikumar. "Evidencebased development of health and family planning programs in Bangladesh and Ghana," Policy Research Division Working Paper no. 175. New York: Population Council.

Reducing unsafe abortion

Espinoza, H. and L. Lopez-Carillo. “Unsafe abortion in Latin America and the Caribbean: Definition of the problem and its prevention," Gaceta Médica de México 139(suppl 1): S9-S15.

Ganatra, Bela and Batya Elul. “Legal but not always safe: Three decades of liberal abortion policy in India," Gaceta Médica de México 139(suppl 1): S102-S108.

Garcia, S.G., D. Lara, and L. Goldman.

"Knowledge, attitudes and practices of medical abortions in Mexico: Results of a national survey," Gaceta Médica de México 139(suppl 1): S91-S101.

Langer, A. “Unwanted pregnancy and unsafe abortion: Health impact in Mexico," Gaceta Médica de México 139(suppl 1): S3-S7.

Lara, D., J. Strickler, S.G. Garcia, H. Martinez, and L. Villanueva. "Access to legal abortion for women who become pregnant as a result of rape in Mexico City," Gaceta Médica de México 139(suppl 1): S77-S90.

Reproductive tract infections and sexually transmitted infections

Dharmaputra, Nick G. and Budi Utomo.

"Investigation of the public health package for STI prevention and care in Central Java and East Java," report of the Safe Motherhood Partnership Family Approach. Jakarta: Population Council. 
Turner, A.N., C. Ellertson, S. Thomas, and S. Garcia. “Diagnosis and treatment of presumed STIs at Mexican pharmacies: Survey results from a random sample of Mexico City pharmacy attendants," Sexually Transmitted Infections 79(3): 224-228.

Verma, Ravi K. “Male sexual health concerns and their implications: Research findings from community-based studies in Mumbai," in Anjali Mahajan (ed.), Perspectives on Culturally Based Concepts of Semen Loss: A Key to Prevention of STIs/HIV. Baroda: Deepak Charitable Trust, pp. 67-77.

Verma, Ravi K., Sumitra Sharma, Rajendra Singh, Gurumurthu Rangaiyan, and Pertti J. Pelto. "Beliefs concerning sexual health problems and treatment seeking among men in an Indian slum community," Culture, Health and Sexuality 5(3): 265-276.

Safe motherhood/postpartum care

Center for Development in Primary Health Care (CDPHC), Al Quds University. "Improving postpartum care among low-parity mothers in Palestine," Frontiers final report. Washington, DC: Population Council.

Hernandez, E. and H. Espinoza. “The El Salvadorian experience with medical treatment of ectopic pregnancy," Gaceta Médica de México 139(suppl 1): S73-S76.

Marsh, D.R., S. Sadruddin, Fariyal F. Fikree, C. Krishnan, and G.L. Darmstadt. "Validation of verbal autopsy to determine the cause of 137 neonatal deaths in Karachi, Pakistan," Paediatric and Perinatal Epidemiology 17(2): 132-142.

Nawar, Laila, Dale Huntington, Ibrahim Kharboush, Nancy Ali, and Mahmoud Shaheen. "Assessment of pilot health project outcome indicators: West Bank/Gaza," Frontiers final report. Washington, DC: Population Council.

Nigenda, G., Ana Langer, C. Kuchaisit, M. Romero, G. Rohas, M. Al-Osimy, J. Villar, J. Garcia, Y. Al-Mazrou, H. Ba'aqeel, G. Carroli, U. Farnot, P. Lumbiganon, J. Belizan, P. Bergsjo, L. Bakketeig, and G. Lindmark. "Women's opinions on antenatal care in developing countries: Results of a study in Cuba, Thailand, Saudi Arabia, and Argentina," BMC Public Health 3: 17

\section{Transitions to Adulthood}

Sathar, Zeba A., Cynthia B. Lloyd, Minhaj ul Haque, Judith A. Diers, Azeema Faizunnisa, Monica Grant, and Munawar Sultana. Adolescents and Youth in Pakistan 2001-02: A Nationally Representative Survey. Islamabad: Population Council.

Livelihoods

\section{Sebastian, Mary Philip, Sohini}

Roychowdhury, Dale Huntington, Aditya Narayan Singh, Meetu Kalkot, and Nirmala Selvam. "Integrating adolescent livelihoods activities within a reproductive health program for slum dwellers in India," Frontiers trainers' guide. New Delhi: Population Council.

\section{Schooling}

Lloyd, Cynthia B. "Education," in Paul Demeny and Geoffrey McNicoll (eds.), Encyclopedia of Population, vol. 1. New York: Macmillan Reference USA, pp. 278-283.
Lloyd, Cynthia B. and Paul C. Hewett.

"Primary schooling in sub-Saharan Africa:

Recent trends and current challenges," Policy Research Division Working Paper no. 176. New York: Population Council.

Sathar, Zeba A., Cynthia B. Lloyd, Cem Mete, and Minhaj ul Haque. "Schooling opportunities for girls as a stimulus for fertility change in rural Pakistan," Economic Development and Cultural Change 51(3): 677-698.

\section{Other Council Publications}

Population Briefs 9(3)

More than 13 million children have

lost one or both parents to HIV/AIDS.

By 2010 , parents of 25 million children will have died.

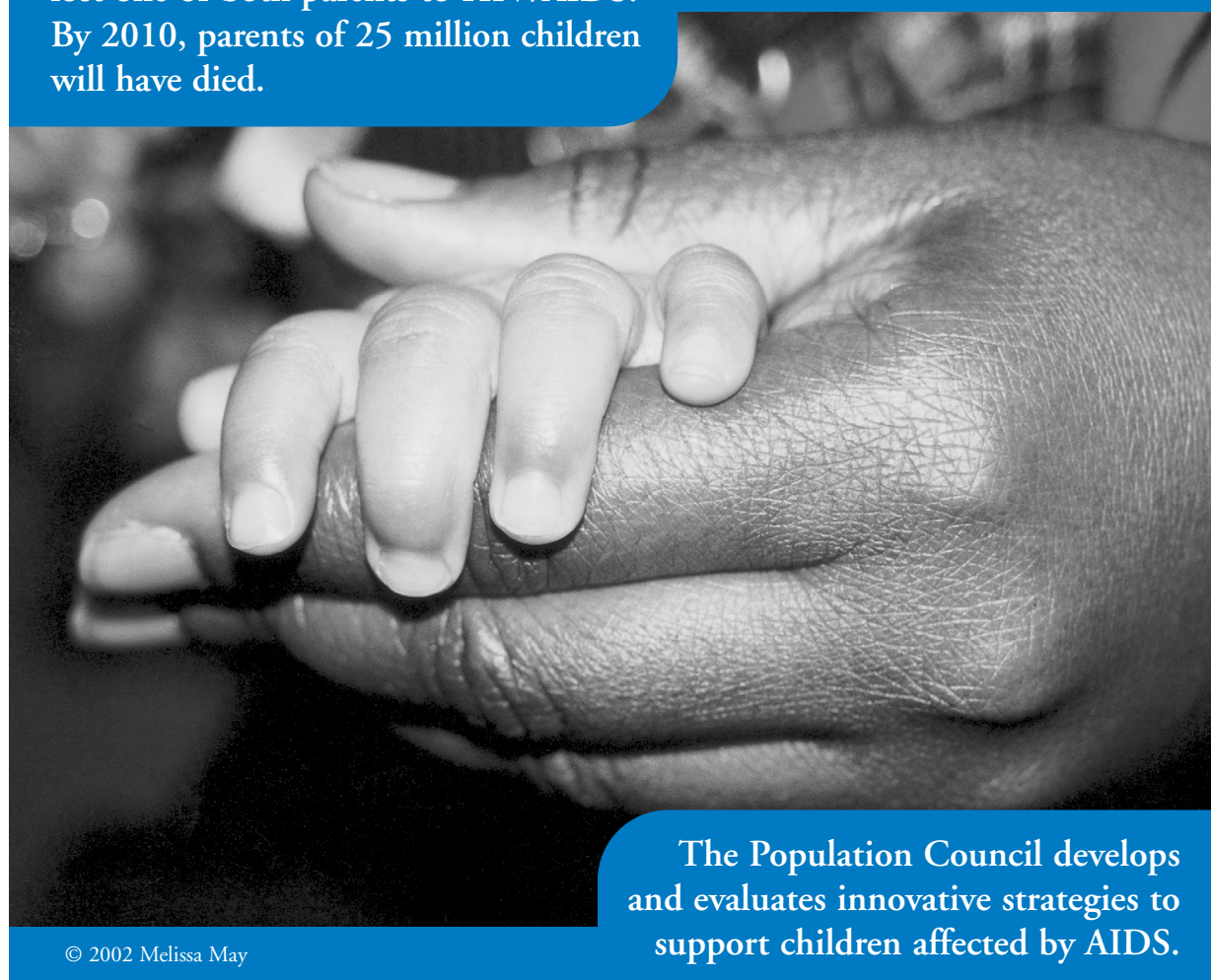

The Population Council conducts biomedical, public health, and social science research on global issues, including reproductive

health, HIVIAIDS, and population trends.
1 Population Council

RESEARCH THAT MAKES A DIFFERENCE pubinfo@popcouncil.org www.popcouncil.org/now telephone 212-339-0500 facsimile 212-755-6052 


\section{Education}

continued from page 1

\section{Findings}

When Lloyd and Hewett compared the data from UNESCO and the DHS, they found that enrollment ratios derived from UNESCO tended to be higher than attendance rates derived from the DHS. This finding provides strong evidence that, in at least some countries, some portion of officially recorded enrollments does not represent regular school attendance. Additionally, UNESCO enrollment estimates imply much larger gender gaps in school participation than do DHS attendance estimates.

The investigators also compared DHS and UNESCO data on grade four completion. To derive this figure, UNESCO determines the ratio of the number of children enrolled in grade five relative to the number enrolled in grade one four years earlier. This measure does not account for grade repetition or temporary withdrawal, however. An alternative measure from the DHS that does not have these limitations is the percent of 15-19-year-olds who have completed four or more years among those who have ever entered school.

Lloyd and Hewett found that, by and large, DHS estimates of the number of children

While the gender gap

is narrowing, a large

schooling gap exists

between the poorest

and wealthiest

\section{households.}

who complete grade four are higher for both boys and girls than are the UNESCO estimates. "We suspect this is because the DHS measure is not time bound and includes students who take more than four years to complete grade four," they write. "In our opinion, the DHS data provide an alternative and potentially more accurate portrayal of past educational achieve- ment and current challenges than trends derived from the UNESCO data."

\section{DHS data}

The researchers then used the DHS data to thoroughly examine trends in schooling in sub-Saharan Africa. Trends in schooling can be discerned using a single survey by comparing the educational experiences of people in different age groups. Lloyd and Hewett looked at the percent of individuals who completed four or more grades and the percent who completed primary school.

For boys, the percent completing primary school is estimated to have risen in subSaharan Africa from roughly 46 percent in the late 1960s to about 57 percent in the late 1990s. Most of the improvement occurred in the 1960s and 1970s. Over the same period of time, girls' primary school completion rate rose from a much lower base, around 26 percent, to 53 percent. As with boys, the pace of progress has largely slowed in the last 20 years. These trends, however, have closed the education gender gap considerably.

Grade four completion rates are slightly higher than primary completion rates for both boys and girls. This discrepancy indicates an attrition rate between the end of grade four and the end of primary school of roughly 10 percentage points. There has also been a small recent decline in grade four completion rates for boys, a trend that may point to future erosion in boys' schooling.

These long-term trends mirror economic and political developments in the region as a whole. In the 1960s and 1970s, strong economic growth allowed for impressive educational expenditures. In the 1980s, however, stagnating economies, political unrest, and rapid population growth conspired to curtail these investments. One result of these cuts has been the assessment of schooling fees in many countries. Thus, poorer families may be less able to send their children to school.

Unlike the UNESCO data, the DHS data allow investigation of the effect of wealth on schooling. This investigation shows that while the gender gap is narrowing, a large schooling

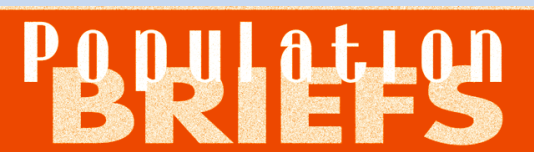

January 2004

Vol. 10, No. 1

Population Briefs is a research newsletter of the Population Council. The Council is an international, nonprofit, nongovernmental organization that seeks to improve the wellbeing and reproductive health of current and future generations around the world and to help achieve a humane, equitable, and sustainable balance between people and resources. The Council conducts biomedical, social science, and public health research and helps build research capacities in developing countries. Established in 1952, the Council is governed by an international board of trustees. Its New York headquarters supports a global network of regional and country offices.

Writers

Gina Duclayan, Christina Horzepa

Editor

Melissa May

Production Manager

Y. Christina Tse

Production Artist

Sura Rosenthal

Copyeditor

Robert Heidel

Editorial Assistant

Jared Stamm

Circulation

Debra Warn

Population Briefs is distributed without charge. Information in this newsletter may be reproduced without permission, provided it is distributed without charge and the source is acknowledged.

\section{Population Council}

One Dag Hammarskjold Plaza

New York, NY 10017

fax: (212) 755-6052

e-mail: pubinfo@popcouncil.org

http://www.popcouncil.org

To receive e-mail when a new issue of Population Briefs is posted to the Population Council Web site, register at our Medi Center: www.popcouncil.org/mediacenter/lists/default.html ISSN 1084-6786

(C)2004 The Population Council, Inc.

Printed in the USA on recycled paper

gap exists between the poorest and wealthiest households.

"Our research highlights the numerous gaps that still need to be addressed to reach the Education for All goals. Creating new strategies to address these challenges will require adequate data. The data now being collected by UNESCO may not provide all the information necessary, particularly for developing programs to help the poorest parents and their children," states Lloyd.

\section{SOURCE}

Lloyd, Cynthia B. and Paul C. Hewett. 2003. "Primary schooling in sub-Saharan Africa: Recent trends and current challenges." Policy Research Division Working Paper no. 176. New York: Population Council. 